\title{
Investment location selection: Strategies for foreign direct investment in Vietnam
}

\author{
$\underline{\text { L. T. Ho }}^{\text {a (D), C. Gan }}{ }^{\text {a }}$ and B. Hu ${ }^{\text {a }}$ \\ ${ }^{a}$ Lincoln University, Canterbury, New Zealand \\ Email:Linh.Ho@lincoln.ac.nz
}

\begin{abstract}
Foreign direct investment distribution is unequal in terms of economic activities as well as among regions, provinces and cities within countries. Therefore, understanding reasons why foreign investors favour a location over others are necessary for policymakers, governments, and international investors. Although determinants of selecting investment locations have been studied, different determinants are identified in different countries. Additionally, studies on the investment location selection within a country are limited, especially in Vietnam. This gives rise to questions which factors make a location more attractive to the foreign investors and whether they have similar effects in different provinces and cities within a country.
\end{abstract}

This paper aims to investigate the determinants of investment location selection at the provincial level in Vietnam based on foreign investors' perspectives. The four groups of factors include human capital, economic, provincial competition and institutional, and infrastructure. The study uses panel data set with 63 Vietnam provinces and cities from 2000 to 2015 . The ordinary least squares estimation supported by the Hausman test is employed in the empirical estimation. The results of models with and without a lag term are robust.

Unlike many previous studies, we employs retail sales of goods and services instead of gross domestic product to represent economic growth at the provincial level. The provincial competitiveness index is employed to represent economic governance of provinces and cities. The investment incentive policies index is proposed as the aggregate index of three types of investment incentives (free land, income tax exemption, and import tax exemption) instead of considering only tax incentives. The country risk index is proposed to represent the political stability and security. Ranking of provinces and cities based on their socio-economic conditions is employed to investigate the different effects of the determinants in different areas in Vietnam.

Surprisingly, this study shows that foreign investors tend to invest more in areas with fewer investment incentives. Additionally, foreign direct investment flows into Vietnam increased after the financial crisis in 2008 as foreign investors may take advantage of lower value currency and lower cost in the areas offering high investment incentives. The effect of infrastructure development on investment location selection is weaker in areas under more difficult socio-economic conditions. This study suggest that Vietnamese policymakers and provincial governments should invest more in education and training, control exchange rate and inflation rate, enhance investment efficiency, maintain political stability and security, improve infrastructure to boost economic growth, and improve economic governance in addition to offering more investment incentives.

Keywords: Investment location selection, foreign direct investment, investment incentive policies, provincial competitiveness index, country risk index 


\section{INTRODUCTION}

Foreign direct investment (FDI) brings economic, political, social, and natural environment effects to a host country (Pazienza, 2014). Identifying the determinants in selecting investment locations from the investors' viewpoint is necessary for home countries to understand why the capital distribution is unequal among economic activities and among areas within the countries.

However, studies related to investors' decisions about where to locate capital is limited. In addition, different researchers identify different institutional factors that have significant effects on choosing investment locations. Some of the identified factors are investment liberalization (UNCTAD, 2018), economic governance (VCCI, 2016), improved democracy (Hasan \& Mahvash, 2015), higher education levels and lower delinquency rates (Escobar, 2013), and political stability and security (Castiglione et al., 2012).

Investors' subjective decisions in choosing the investment's location are important to the economic growth and development of host countries. However, few researchers (Hoang \& Goujon, 2014; Vu et al., 2009; Nguyen \& Nguyen, 2007) have focused on this topic in Vietnam and their results are inconsistent. Hoang and Goujon (2014, p. 103) find "a dominance of the regional trade platform FDI and regional agglomeration effects". Vu et al. (2009) investigated the determinants in selecting investment locations based on mining and quarrying industry data. The results do not show any factors impacting FDI projects' location in all industries at the provincial level in Vietnam. Using spatial econometric models to investigate the determinants of the FDI distribution at the Vietnam provincial level, Nguyen and Nguyen (2007) find the concentration of foreign investors in certain locations because of the market, labour availability, infrastructure and investors' nationalities.

To attract foreign investors, countries compete for FDI by implementing several investment incentives (Haaparanta, 1996). These forms of investment incentives include grants, tax preferences or holidays, free land or other inputs, and regulatory policy concessions, etc. (Thomas, 2009). The investment incentive policies (IIP) such as regional tax policy (Li \& Shen, 2008; Sun, 2002), environmental policy (Zhu et al., 2011), policies of land-use fee, corporate income tax, fee holidays, or services for FDI projects (Oman, 2000) make some regions more favourable in competing for limited fund from abroad.

Our study differs from the previous studies in the following ways. Our study investigates the determinants of investment location selection at the provincial level in Vietnam based on the foreign investors' perspective. Interestingly, the results show that foreign investors tend to invest more into areas offering fewer investment incentives, which is different from the findings of Hoang and Goujon (2014), Vu et al. (2009), Li and Shen (2008), and Oman (2000). The proposed IIP index includes free land, income tax and import tax exemption instead of considering only tax incentives in previous studies such as Wei and Li (2011), Li and Shen (2008), and Sun (2002).

Surprisingly, FDI flows into Vietnam increased after the financial crisis in 2008 as foreign investors may take advantage of lower value currency and lower cost in the areas offering high investment incentives. The effect of infrastructure development on investment location selection is weaker in areas under more difficult socioeconomic conditions. The results suggest Vietnamese policymakers and provincial governments should invest more in education and training, control exchange rate and inflation rate, enhance investment efficiency, maintain political stability and security, improve infrastructure to boost economic growth, and improve economic governance in addition to offering more investment incentives.

The study suggests academia employs retail sales of goods and services (RS) instead of gross domestic product (GDP) to represent economic growth at non-national levels. This is because RS reduces the limitations of the GDP calculation at the non-national levels. Additionally, the country risk (CR) index is proposed to represent the political stability and security as one of institutional factors that impact strategic decisions of foreign investors in Vietnam.

The paper is organised as follows. Section 2 discusses the literature and hypotheses development. Section 3 describes the econometric models. Section 4 presents the study data. Section 4 reports the main results and conclusions.

\section{LITERATURE REVIEW}

The determinants of FDI encouraging foreign investors to invest in one single country or a single location have been studied by many researchers such as Hasan \& Mahvash (2015), Omri \& Kahouli (2014), Razmi \& Behname (2012), and Haq (2001). These determinants have been considered as FDI-attractive factors which make some regions more favourable in competing for limited fund from abroad than others. To identify the 
FDI-attractiveness or FDI-competitive determinants, some studies conducted empirical analyses at the national levels (Kinuthia \& Murshed, 2015; Labes, 2015; Thanyakhan, 2008; and Haq, 2001), and others at the subnational levels (Castiglione et al., 2012; Pradhan, 2012; Wei \& Li, 2011; and Sun, 2002).

The FDI competition using investment incentives is a worldwide phenomenon at all levels of governments including the national and sub-national levels (Oman, 2000). UNCTAD (2018) documents that investment incentives are one of the most common investment policy tools for industrial development in the world from 2010 to 2017. The IIP or institutional structures have been used as subsidies to affect FDI flows. Foreign investors make strategic decisions on where and how to set up their operations based on the institutional structures (such as grants, tax preferences or holidays, free land or other inputs, and regulatory policy concessions) that vary not only among countries, but also within the host economy (Thomas, 2009).

Some China-related studies investigate the effects of policies on attracting FDI among provinces of the country. At the provincial level, Sun (2002) finds that regional tax competition does exist, and taxation is still an important factor affecting the spatial distribution of FDI, but its role has been weakened over time. The study of $\mathrm{Li}$ and Shen (2008) also suggests that the provincial competition strategies expanded from the pure tax price to the government expenditure in China because of the different levels of economic development. Similarly, Wei and Li (2011) results support that a better performance of economic growth other than tax incentives is likely to be a more significant factor in attracting FDI in central and eastern region of China compared with the relatively underdeveloped western region. According to the empirical results of Zhu et al., (2011), in neighbouring municipalities, environmental policy could be taken into consideration in competing for FDI and compared with the regions with high level of FDI. The study shows the effect of "race to the bottom" of environmental policy may be higher in the regions with lower level of FDI.

In Vietnam, studies about the effects of policies on FDI in Vietnam are limited and the results from some empirical studies are inconsistent. Vietnamese provincial governments issued extra legal documents granting extra incentives of tax and land, and extended exemption periods to investment projects ( $\mathrm{Vu}$ et al., 2007). $\mathrm{Vu}$ (2007) reveals that in provinces adopting extra-legal incentives, there is a decrease in the amount of FDI per capita received the year after adoption of those incentives. However, according to Vu et al. (2009), Vietnam made the greatest efforts to regulate sub-national incentives; and provincial policies were identified as important factors to attract more FDI (Hoang \& Goujon, 2014). Therefore, whether investment incentives reduce or raise the amount of FDI or make any differences in the investment location selection at the provincial level in Vietnam is debatable.

An institutional factor in attracting FDI at the sub-national level in Vietnam is the economic governance evaluated by the provincial competitiveness index (PCI) introduced by Vietnam Chamber of Commerce and Industry (VCCI). PCI was used to evaluate and compare competitiveness of FDI flows, and the relationship between economic governance and FDI attraction in Vietnam in Nguyen and Ho (2013), Nguyen et al. (2012), Malesky (2010), and Nguyen and Nguyen (2007) studies. However, the findings are mixed. While Malesky (2010) found a strong and positive correlation between the PCI and FDI flows in Vietnam provinces and cities, Nguyen et al. (2012) concluded that the provinces or cities with better governance are not strongly associated with higher total registered capital of licensed inward FDI projects in the North Central and South Central Coast areas of Vietnam. In addition, Nguyen and Ho (2013) showed there was a sub-national competition in the 64 provinces to attract FDI, whereas Nguyen and Nguyen (2007) conclude that it is not a significant factor when considering some provinces and other partner countries of Vietnam. Thus, how PCI helps Vietnam provinces and cities to compete for the limited capital of foreign investors is questionable.

\section{MODEL}

The four groups of factors, human capital (HC), economic (EC), provincial competition and institutional (PC), and infrastructure factors (IN), are included in our regression model (1).

$$
F D I_{i t}=\alpha_{0}+\sum_{m=1}^{M} \beta_{m} H C_{m i t}+\sum_{k=1}^{K} \mu_{k} E C_{k i t}+\sum_{q=1}^{Q} \varphi_{q} P C_{q i t}+\sum_{p=1}^{P} \vartheta_{p} I N_{p i t}+\sum_{r=1}^{R} \omega_{r} P R 2_{i t} X_{r i t}+\delta_{i}+\gamma_{t}+e_{i t}(1)
$$

where $\alpha, \beta, \mu, \varphi, \vartheta$ and $\omega$ are parameters; $e$ is error terms; $H C_{m i t}, E C_{k i t}, P C_{q i t}$, and $I N_{\text {pit }}$ are $m, k, q$, and $p$ variables of the four groups of factors, respectively; $P R 2_{i t}$ is province ranking and $X_{\text {rit }}$ are $\mathrm{r}$ variables in interaction terms with PR2; $i$ stands for provinces or cities; $t$ stands for years; $\delta$ is the fixed effect for each crosssection; and $\gamma$ is the random effect for each period. 
Ho et al., Investment location selection: Strategies for foreign direct investment in Vietnam

This study adopts the panel ordinary least squares (OLS) estimation procedure from previous studies such as Hasan and Mahvash (2015), Labes (2015), Nguyen and Ho (2013), and Razmi and Behname (2012) to investigate the determinants of investment location selection at the provincial level in Vietnam. The Hausman test (Hausman, 1978) shows that random effects models are appropriate for our empirical estimation.

Table 1 shows the four groups of variables impact on FDI in selected references and the variables of each group used in this study.

Table 1. Groups of Variables

\begin{tabular}{|c|c|c|c|c|}
\hline $\begin{array}{l}\text { Variable } \\
\text { group }\end{array}$ & $\begin{array}{l}\text { Variable used in } \\
\text { previous studies }\end{array}$ & $\begin{array}{l}\text { Impact } \\
\text { on FDI }\end{array}$ & Reference & $\begin{array}{l}\text { Variable used } \\
\text { in this study }\end{array}$ \\
\hline $\begin{array}{l}\text { Human } \\
\text { capital factor }\end{array}$ & Education level & PS & $\begin{array}{l}\text { Kumari (2014), Omri and Kahouli (2014), Escobar } \\
\text { (2013), Zhao and Xiang (2012), Huang and Chai (2006) }\end{array}$ & EDU \\
\hline \multirow{7}{*}{$\begin{array}{l}\text { Economic } \\
\text { factors }\end{array}$} & $\begin{array}{l}\text { Economic Growth } \\
\text { (GDP) }\end{array}$ & PS & $\begin{array}{l}\text { Nguyen et al. (2012), Hoang, Wiboonchutikula, and } \\
\text { Tubtimtong (2010), Srinivasan et al. (2010), Thanyakhan } \\
\text { (2008), Kornecki and Rhoades (2007) }\end{array}$ & RS \\
\hline & Exchange Rate & PS & $\begin{array}{l}\text { Kinuthia and Murshed (2015), Labes (2015) } \\
\text { Haq (2001) }\end{array}$ & ER \\
\hline & $\begin{array}{c}\text { Investment } \\
\text { efficiency }\end{array}$ & PS & Kumari (2014) & ICOR \\
\hline & Labour cost & NS & Kinuthia and Murshed (2015), Malesky (2010) & INC \\
\hline & \multirow{2}{*}{ Inflation } & PS & Kinuthia and Murshed (2015) & \multirow{2}{*}{ CPI } \\
\hline & & NS & Hasan and Mahvash (2015), Razmi and Behname (2012) & \\
\hline & Financial crisis & NS & & CRI \\
\hline \multirow{5}{*}{$\begin{array}{l}\text { Provincial } \\
\text { competition } \\
\text { and } \\
\text { institutional } \\
\text { factors }\end{array}$} & \multirow{2}{*}{$\begin{array}{c}\text { Economic } \\
\text { governance }\end{array}$} & PS & Malesky (2010) & \multirow{2}{*}{ PCI } \\
\hline & & $\mathrm{I}$ & Nguyen et al. (2012), Nguyen and Nguyen (2007) & \\
\hline & \multirow{2}{*}{$\begin{array}{c}\text { Investment } \\
\text { incentives (tax) }\end{array}$} & PS & $\begin{array}{l}\text { Hoang \& Goujon (2014), Wei and Li (2011), Thomas } \\
\text { (2009), Vu et al. (2009), Li and Shen (2008), Sun (2002) }\end{array}$ & \multirow[t]{2}{*}{ IIP } \\
\hline & & NS & $\mathrm{Vu}(2007)$ & \\
\hline & $\begin{array}{l}\text { Political stability } \\
\text { and security }\end{array}$ & PS & Castiglione et al. (2012) & $\mathrm{CR}$ \\
\hline \multirow{3}{*}{$\begin{array}{l}\text { Infrastructure } \\
\text { factors }\end{array}$} & \multirow{3}{*}{$\begin{array}{l}\text { Infrastructure } \\
\text { development }\end{array}$} & \multirow{3}{*}{ PS } & \multirow{3}{*}{$\begin{array}{l}\text { Kinuthia and Murshed (2015), Hasan and Mahvash } \\
\text { (2015), Castiglione et al. (2012), Pradhan (2012) }\end{array}$} & GF \\
\hline & & & & BED \\
\hline & & & & WEB \\
\hline $\begin{array}{l}\text { Province } \\
\text { Ranking }\end{array}$ & - & - & - & PR2 \\
\hline
\end{tabular}

Mukherjee (2014) used RS to identify the relationship between growth in RS and FDI in India from 1975 to 2010. In Mukherjee's study, private final consumption is employed as a proxy for retail sales ${ }^{1}$, which is an important component of GDP. Jude and Masca (2009) employed consumption to examine the interdependence of FDI in Romania from 2000 to 2006 and the results show the impact of FDI on consumption indirectly affects economic growth.

$\mathrm{RS}$ is used to represent economic growth at the provincial level in Vietnam because it can overcome the limitations of provincial GDP data. First, RS measures consumer spending which is a component of GDP. According to the US Census Bureau (2008), RS is defined as finished goods and services sold to consumers at the end of the supply chain, generally without transformation, over a specified time period. Following the expenditure approach, GDP is calculated based on the final goods and services purchased by individuals, businesses, governments, and foreigners (Pritzker et al., 2015). Hence, RS can reflect consumer spending patterns impacting GDP of the economy. In other words, an increase or a decline in RS can be a positive or negative signal of economic growth, respectively.

Second, while GDP is calculated at the country level (VnExpress, 2014), RS can be used to measure economic growth of regions, provinces or cities. This is because RS calculates finished goods and services sold to retailers (the US Census Bureau, 2008), which does not result in the overlap of calculation.

Third, RS highly correlates with GDP in Vietnam based on the data obtained from the Vietnam general statistics office (GSO). A correlation of 0.9974 (close to 1) is found between RS and GDP from 1990 to 2015.

\section{DATA}

Table 2 summarises the definitions and sources of the model variables.

\footnotetext{
${ }^{1}$ According to Mukherjee (2014), the private final consumption includes household expenditures on durable and nondurable goods and services during a certain period. This shows the expenditure patterns of consumers in consumption goods, thus an increase or a decrease in the private final consumption directly relates to the increase or decrease in retail sales.
} 
Ho et al., Investment location selection: Strategies for foreign direct investment in Vietnam

Table 2. Definitions and Data Sources of the Model Variables

\begin{tabular}{|c|c|c|c|}
\hline Variable group & Variable & Definition & Source \\
\hline Human capital factor & EDU & Education level in \% (2000-2015) & GSO \\
\hline \multirow{4}{*}{ Economic factors } & RS & Retail sales at current prices in billion VND (2000-2015) & GSO \\
\hline & ER & Exchange rate VND/USD, annual averaged (2000-2015) & GSO \\
\hline & INC & Monthly average income in thousand VND (2000-2015) & GSO \\
\hline & CPI & Inflation rate (consumer price index), annual averaged (2000-2015) & FXTOP (2017) \\
\hline \multirow{3}{*}{$\begin{array}{l}\text { Provincial competition } \\
\text { and institutional factors }\end{array}$} & PCI & The provincial competitiveness index (2005-2015) & VCCI (2016) \\
\hline & IIP & The investment incentive policies index (2000-2015) [1] & Lawsoft \\
\hline & $\mathrm{CR}$ & The country risk index $(2000-2015)[2]$ & PRS (2017) \\
\hline \multirow{2}{*}{ Infrastructure factors } & GF & Volume of goods freight in thousand tons $(2000-2015)$ & GSO \\
\hline & BED & Number of patient beds in thousand beds $(2002-2015)$ & GSO \\
\hline FDI attraction & FDI & $\begin{array}{l}\text { The total registered capital of licensed inward FDI projects in million } \\
\text { USD }(2000-2015)\end{array}$ & GSO \\
\hline
\end{tabular}

[1] The IIP index including free land, income tax and import tax exemption is constructed based on Vietnam regulations and laws from 2000 to 2015; [2] The CR is proposed based on a political risk index that is one of the three risk subcategories in the International Country Risk Guide (ICRG) from the Political Risk Services (PRS) Group; [3] WEB is constructed based on five factors including availability of more than one language, availability of law documents, economic and social information (on an English page), documents for investment registration (on an English page), and online registration and support (on an English page); [4] PR is based on Vietnam provinces and cities' socio-economic conditions ( $\mathrm{PR}=2$ if extremely difficult, $\mathrm{PR}=1$ if difficult, and $\mathrm{PR}=0$ if non-difficult).

The study period is from 2000 to 2015 . There are three reasons for choosing this period. First, most inward FDI flows into Vietnam were over the 16-year period (the percentages of FDI projects in 2000-2015 and 19881999 are $86.2 \%$ and $14.8 \%$, respectively). Secondly, $75.85 \%$ of the total FDI registered capital and $86.83 \%$ of the total FDI implemented capital occurred during 2000-2015. Thirdly, data before 2000 at the provincial level were not well developed and updated compared with the data at the national level.

As of $31^{\text {st }}$ December 2015, there are 63 Vietnam administrative units (five cities and 58 provinces) (GSO, 2016). However, the total number of units has changed over time. The number rose from 38 in 1976 to 44 in 1989, increased to 53 in 1991 and to 61 units in 1997 (VOER, 2017). In 2004, Can Tho city and Hau Giang province were established from Can Tho province, the old Lai Chau province was divided into new Lai Chau and Dien Bien, and old Dak Lak province was divided into new Dak Lak and Dak Nong (Assembly, 2008). Therefore, the number of units increased to 64 in 2004. From 2008 onwards, the total reduced to 63 units as Ha Tay province merged with Ha Noi city. As a result, data recorded at the provincial level also changed, resulting in no available data either for the new administrative units (Hau Giang, Dien Bien and Dak Nong) before establishment in 2004 or for the old unit, Ha Tay, after it merged with Ha Noi city in 2008.

Our study uses panel data at the provincial level from 2000 to 2015. However, the number of administrative units increased from 61 (2000-2003) to 64 (2004-2008) but decreased then to 63 units (2008-2015). Therefore, if all 64 units were included in the panel data, there will be missing data points. To minimise the number of missing data points at the provincial level, the data of 64 units are combined into the 60 cross-units.

\section{DISCUSSION AND CONCLUSION}

Table 3 show the results of the determinants of investment location selection at the provincial level and their effects in different Vietnam provinces and cities. First, we found that foreign investors are more likely to invest in provinces and cities with better governance (higher PCI). Secondly, investment incentives did not play an effective role in enhancing the FDI competition ability of the provinces and cities. Offering free land, income tax and import tax exemption contributing to the IIP index is less likely to attract more FDI at the provincial level over the study period 2000-2015. Foreign investors value the economic governance as a positive factor of local investment environment; and do not highly consider low costs of land use and tax to select investment locations. The study results suggest policymakers should focus on improving the investment environment to attract the foreign investors in addition to offering more investment incentives in Vietnam.

Other findings show that the risk level (the CR index) and the financial crisis in 2008 negatively impact on FDI attraction at the provincial level in Vietnam, which aligns with the findings of Castiglione et al. (2012) that the political stability is an important institutional factor attracting investors' interest. However, investors are likely to invest in areas under extremely difficult socio-economic condition after the 2008 financial crisis to take 
advantage of lower costs offered in the areas using high investment incentive policies (free land and tax exemption). In addition, at the provincial level in Vietnam, the education level (EDU), economic growth (RS), inflation rate (CPI), exchange rate (ER), and investment efficiency (ICOR) are important factors. The effect of infrastructure development (GF) on FDI attraction is positive and significant over the study period. However, the effect of infrastructure on FDI attraction is weaker in provinces with more difficult socio-economic conditions. The results suggest that policymakers and provincial governments should maintain the political stability and security, invest more on fields of education and training, control the inflation and exchange rates, improve infrastructure, and enhance the investment efficiency.

Table 3. Coefficients of the Regressors with FDI Location Selection at the Provincial Level in Vietnam

\begin{tabular}{|c|c|c|c|c|c|c|c|c|c|c|c|c|c|c|c|c|c|c|c|c|c|}
\hline \multirow{2}{*}{$\begin{array}{l}\text { Variable } \\
\text { group }\end{array}$} & \multirow[b]{2}{*}{ Variable } & \multicolumn{10}{|c|}{ Estimation without a time lag } & \multicolumn{10}{|c|}{ Estimation with a time lag } \\
\hline & & \multicolumn{5}{|c|}{$2000-2015$} & \multicolumn{5}{|c|}{$2005-2015$} & \multicolumn{5}{|c|}{$2000-2015$} & \multicolumn{5}{|c|}{$2005-2015$} \\
\hline $\begin{array}{l}\text { Human } \\
\text { capital factor }\end{array}$ & EDU [1] & PS & PS & PS & PS & PS & PS & PS & PS & PS & PS & PS & PS & PS & PS & PS & PS & PS & PS & PS & PS \\
\hline EG & RS [1] & PS & PS & PS & PS & PS & PS & PS & $\mathrm{P}$ & PS & PS & PS & PS & PS & PS & PS & PS & PS & PS & PS & PS \\
\hline \multirow{3}{*}{$\begin{array}{l}\text { Economic } \\
\text { factors }\end{array}$} & ER & PS & PS & PS & PS & PS & PS & PS & PS & PS & PS & PS & PS & $\mathrm{PS}$ & PS & PS & PS & PS & PS & PS & PS \\
\hline & ICOR & PS & PS & PS & PS & PS & $\mathrm{P}$ & $P$ & $\mathrm{P}$ & $\mathrm{P}$ & $\mathrm{P}$ & NS & NS & NS & $\mathrm{NS}$ & NS & NS & NS & NS & NS & $\mathrm{NS}$ \\
\hline & CRI & $\mathrm{NS}$ & $\mathrm{NS}$ & $\mathrm{NS}$ & $\mathrm{NS}$ & $\mathrm{NS}$ & $\mathrm{NS}$ & $\mathrm{NS}$ & $\mathrm{NS}$ & NS & $\mathrm{NS}$ & $\mathrm{P}$ & $\mathrm{P}$ & $\mathrm{N}$ & $\mathrm{N}$ & $\mathrm{P}$ & $\mathrm{N}$ & $\mathrm{N}$ & $\mathrm{N}$ & $\mathrm{NS}$ & $\mathrm{N}$ \\
\hline \multirow{3}{*}{$\begin{array}{l}\text { Provincial } \\
\text { competition } \\
\text { and } \\
\text { institutional } \\
\text { factors }\end{array}$} & PCI [2] & & & & & & PS & PS & PS & PS & PS & & & & & & PS & PS & PS & PS & PS \\
\hline & IIP & NS & $\mathrm{N}$ & $\mathrm{N}$ & $\mathrm{N}$ & $\mathrm{N}$ & $\mathrm{N}$ & $\mathrm{P}$ & $\mathrm{P}$ & $\mathrm{P}$ & $\mathrm{P}$ & NS & NS & NS & NS & $\mathrm{N}$ & NS & $\mathrm{N}$ & $\mathrm{N}$ & $\mathrm{N}$ & $\mathrm{N}$ \\
\hline & $\mathrm{CR}$ & $\mathrm{N}$ & $\mathrm{N}$ & $\mathrm{P}$ & $\mathrm{P}$ & $\mathrm{P}$ & $\mathrm{P}$ & $\mathrm{P}$ & $\mathrm{P}$ & $\mathrm{P}$ & $\mathrm{P}$ & PS & PS & PS & PS & PS & PS & PS & PS & PS & PS \\
\hline $\begin{array}{l}\text { Infrastructure } \\
\text { factors }\end{array}$ & GF & PS & $\mathrm{PS}$ & PS & PS & PS & PS & PS & PS & PS & PS & PS & $\mathrm{PS}$ & $\mathrm{PS}$ & PS & PS & PS & PS & PS & PS & $\mathrm{PS}$ \\
\hline \multirow{5}{*}{$\begin{array}{l}\text { Interaction } \\
\text { terms }\end{array}$} & CRI*PR2 & & & $\mathrm{P}$ & $\mathrm{N}$ & & & & $\mathrm{P}$ & $\mathrm{P}$ & & & & $\mathrm{P}$ & $\mathrm{P}$ & & & & $\mathrm{P}$ & $\mathrm{P}$ & \\
\hline & CR*PR2 & & & $\mathrm{N}$ & $\mathrm{N}$ & & & & $\mathrm{N}$ & $\mathrm{P}$ & & & & $\mathrm{N}$ & $\mathrm{N}$ & & & & $\mathrm{P}$ & $\mathrm{P}$ & \\
\hline & GF*PR2 & & & $\mathrm{NS}$ & & PS & & & $\mathrm{NS}$ & & $\mathrm{P}$ & & & PS & & $\mathrm{NS}$ & & & $\mathrm{P}$ & & $\mathrm{NS}$ \\
\hline & BED*PR2 & & & $\mathrm{N}$ & & NS & & & $\mathrm{P}$ & & $\mathrm{N}$ & & & $\mathrm{N}$ & & $\mathrm{P}$ & & & $\mathrm{N}$ & & $\mathrm{P}$ \\
\hline & WEB*PR2 & & & $\mathrm{P}$ & & $\mathrm{N}$ & & & $\mathrm{N}$ & & $\mathrm{N}$ & & & $\mathrm{P}$ & & $\mathrm{P}$ & & & $\mathrm{P}$ & & $\mathrm{P}$ \\
\hline
\end{tabular}

PS is positive and significant; NS is negative and significant; $\mathrm{P}$ is positive and insignificant; $\mathrm{N}$ is negative and insignificant; [1] There is a lag term in the variables RS, EDU, CPI in estimations with a time lag; [2] The estimations 1-5 from 2000 to 2015 are without PCI as PCI is only available from 2005.

Ranking of provinces in Vietnam, proposing the IIP, CR, and WEB indices are the first efforts to better identify the FDI location selection's determinants at the provincial level in Vietnam based on foreign investors' perspective. Future research should include a wider range of investment incentives such as grants, holidays, policy concessions and consider different techniques to construct the IIP index such as surveys to reflect the investors' opinions. Questionnaires would also improve the CR index to enable future researchers to investigate the FDI location selection based on the investors' evaluations. Future research should expand the sample size to explore the longer impacts of economic governance (PCI) at the provincial level. Additionally, PCI-subindices would be taken into consideration to enrich the study on the determinants of FDI location selection from foreign investors' point of view.

\section{REFERENCES}

Assembly, T. N. (2008). Resolution No. 15/2008/QH12 on adjusting administrative boundaries of Hanoi city and related provinces. Viet Nam. Retrieved from http://thuvienphapluat.vn/vanban

Castiglione, C., Gorbunova, Y., Infante, D., \& Smirnova, J. (2012). FDI determinants in an idiosyncratic country. A reappraisal over the Russian regions during transition years. Communist and Post-Communist Studies, 45(1-2), 1-10.

Escobar, G. O. R. (2013). Foreign direct investment (FDI) determinants and spatial spillovers across Mexico's states. The Journal of International Trade \& Economic Development, 22(7), 993-1012.

FXTOP. (2017). Historical Exchange Rates. Statistical Data Retrieved 05/10/2017 http://fxtop.com/en/exchange-rates

GSO. (2016). Number of administrative units as of 31 December 2015 by province. Available from General Statistics Office of Vietnam Statistical Data Retrieved 17/10/2016 https://www.gso.gov.vn/default en.aspx?tabid=773

Haq, K. (2001). An analysis of the determinants of United States direct investment abroad in the manufacturing sector (PhD thesis). State University of New York at Buffalo, Ann Arbor. Retrieved from ABI/INFORM Complete; ProQuest Central database. (251038131)

Hasan, F., \& Mahvash, M. (2015). Determinants of FDI: Does democracy matter? Journal of Business Systems, Governance and Ethics(2). Hausman, J. A. (1978). Specification tests in econometrics. Econometrica, 46, 1251-1272.

Hoang, H. H., \& Goujon, M. (2014). Determinants of Foreign Direct Investment in Vietnamese provinces: A spatial econometric analysis. Post-Communist Economies, 26(1), 103-121.

Hoang, T. T., Wiboonchutikula, P., \& Tubtimtong, B. (2010). Does Foreign Direct Investment promote economic growth in Vietnam? ASEAN Economic Bulletin, 27(3), 295-311.

Huang, X. Q., \& Chai, M. (2006). The selection of FDI regions according to the new economic geography: A case study based on China's inter-provincial panel data. Management World, 22(10), 7-13. 
Ho et al., Investment location selection: Strategies for foreign direct investment in Vietnam

Jude, C., \& Masca, S. G. (2009). The vicious circle of FDI and consumption in Romania. Annals of the University of Oradea: Economic Science, 2(1), 417-423.

Kinuthia, B. K., \& Murshed, S. M. (2015). FDI determinants: Kenya and Malaysia compared. Journal of Policy Modeling, 37(2), 388400 .

Kornecki, L., \& Rhoades, D. (2007). How FDI facilitates the globalization process and stimulates economic growth in CEE. Journal of International Business Research, 6(1), 113-126.

Kumari, J. (2014). Foreign Direct Investment and economic growth: A literature survey. BVIMSR's Journal of Management Research, $6(2), 118-127$

Labes, S.-A. (2015). FDI determinants in BRICS. CES Working Papers, 7(2), 296-308.

Li, Y. Y., \& Shen, K. R. (2008). Competition among jurisdictions, strategical fiscal policies, and regional characteristics of FDI's growth achievements. Economic Research Journal, 54(5), 58-68.

Malesky, E. J. (2010). Provincial Governance and Foreign Direct Investment in Vietnam. In S. E. Times (Ed.), 20 Years of Foreign Investment: Reviewing and Looking Forward (1987-2007). Vietnam: Knowledge Publishing House. Retrieved from $\underline{\mathrm{http}: / / \mathrm{ssrn} . \mathrm{com} / \mathrm{abstract}=1669742}$

Mukherjee, D. (2014). Econometric analysis of the impact of FDI on retail trade in India. IOSR Journal of Business and Management (IOSR-JBM), 16(5), 01-07.

Nguyen, D. C., \& Ho, T. L. (2013). Is there strong bidirectional causality between FDI and economic growth? New evidence on Vietnam. Journal of Transformative Entrepreneurship, 1(1), 25-38.

Nguyen, D. C., Ho, T. L., \& Zhang, K. Z. (2012). FDI in the North Central and South Central Coast areas of Vietnam: A bidirectional relationship with GDP, a competition among provinces, and effects of laws. Journal of Science, Hue University, 72B(3), 47-56.

Nguyen, N. A., \& Nguyen, T. (2007). Foreign Direct Investment in Vietnam: An overview and analysis the determinants of spatial distribution across provinces. Germany: Munich Personal RePEC Archive (MPRA) Paper. Retrieved from https://mpra.ub.unimuenchen.de/1921/

Oman, C. P. (2000). Policy Competition for Foreign Direct Investment: A Study of Competition Among Governments to Attract FDI. Paris: OECD.

Omri, A., \& Kahouli, B. (2014). The nexus among foreign investment, domestic capital and economic growth: Empirical evidence from the MENA region. Research in Economics, 68(3), 257-263.

Pazienza, P. (2014). The relationship between FDI and the natural environment: Facts, evidence, and prospects. The Netherlands: Springer International Publishing AG. doi:10.1007/978-3-319-04301-2

Pradhan, R. P. (2012). Dynamic panel data model and FDI determinants in India. IUP Journal of Financial Economics, 10(1), 33-41.

Pritzker, P. S., Arnold, K., \& Moyer, B. C. (2015). Measuring the Economy: A Primer on GDP and the National Income and Product Accounts. Washington: US Department of Commerce: Bureau of Economic Analysis.

PRS. (2017). ICRG Methodology. Available from The PRS Group, Inc. Retrieved 16/03/2017 http://www.prsgroup.com/about-us/ourtwo-methodologies/icrg

Razmi, M. J., \& Behname, M. (2012). FDI determinants and oil effects on foreign direct investment: evidence from Islamic countries. Advances in Management and Applied Economics, 2(4), 261-270.

Srinivasan, P., Kalaivani, M., \& Ibrahim, P. (2010). FDI and economic growth in the ASEAN countries: Evidence from cointegration approach and causality test. IUP Journal of Management Research, 9(1), 38-63.

Sun, J. (2002). Factors affecting the location of FDI in China. China Economic Quarterly, 1(3), 687-697.

Thanyakhan, S. (2008). The determinants of FDI and FPI in Thailand: a Gravity model analysis (PhD thesis). Lincoln University, Lincoln, New Zealand. Retrieved from https://researcharchive.lincoln.ac.nz/bitstream/handle/10182/443

Thomas, K. P. (2009). Subnational FDI competition in developing countries: The case of Viet Nam. Paper presented at the meeting of the American Political Science Association (APSA) 2009 Annual Meeting Paper, Toronto, Canada. Retrieved from http://ssrn.com/abstract $=1450115$

UNCTAD. (2018). World Investment Report 2018: Methodological note. United Nations, Geneva. Retrieved from https://unctad.org/en/PublicationChapters/wir2018chMethodNote en.pdf

US Census Bureau. (2008). NAICS Codes, Titles, and Descriptions: Monthly Retail Trade and Food Services. Available from Retail Indicators Branch, US Census Bureau Retrieved 9/11/2016 http://www.census.gov/mrts/

VCCI. (2016). The Provincial Competitiveness Index (PCI). PCI data aggregation Retrieved 23/09/2016, from Vietnam Chamber of Commerce and Industry (VCCI) http://eng.pcivietnam.org/data-catalog/pci-data/

VnExpress. (2014). Tiến sỹ Trần Du Lịch: "Không nên tính GDP theo địa phương". Available from Pháp luật thành phố Retrieved 08/11/2016, from VnExpress http://kinhdoanh.vnexpress.net

VOER. (2017). Phân cấp hành chính Việt Nam. Available from The Vietnam Open Educational Resources Social Sciences Retrieved 09/10/2017 http://voer.edu.vn/m/phan-cap-hanh-chinh-viet-nam/0284519c

$\mathrm{Vu}$, L. (2007). Foreigners poised to celebrate tax parity. Vietnam Investment Review, December 2(1).

Vu, T. T. A., Le, V. T., \& Vo, T. T. (2007). Provincial Extralegal Investment Incentives in the Context of Decentralisation in Viet Nam: Mutually Beneficial or a Race to the Bottom? Hanoi, Vietnam: UNDP Vietnam. Retrieved from http://www.vietnamconsult.de/elib/data

Vu, X. N. H., Ngo, M. T., \& Ho, C. H. (2009). Sustainable Development Impacts of Investment Incentives: A Case Study of the Mining Industry in Vietnam. Canada: The International Institute for Sustainable Development. Retrieved from www.iisd.org/tkn/pdf/sd incentives vietnam.pdf

Wei, L. J., \& Li, Y. (2011). A study of dynamic interaction between FDI and provincial economic development in China: Empirical analysis based on 1988-2008. Journal of Capital University of Economics and Business, 14(2), 52-61.

Zhao, W., \& Xiang, Y. H. (2012). Location advantage, agglomeration economies and competition for FDI among Chinese regions. Journal of Zhejiang University (Humanities and Social Sciences), 42(6), 111-124.

Zhu, P. F., Zhang, Z. Y., \& Jiang, G. L. (2011). Empirical study of the relationship between FDI and environmental regulation: an intergovernmental competition perspective. Economic Research Journal, 57(6), 133-144. 